\title{
THE INFLUENCE OF WORK MOTIVATION TOWARD THE LIBRARIAN'S PERFORMANCE IN UPT LIBRARY OF UNIVERSITAS HASANUDDIN MAKASSAR
}

\author{
Asniati $^{1}$ \\ La Ode Ismail Ahmad ${ }^{2}$ \\ Arifuddin Tike ${ }^{3}$ \\ Postgraduate student of UIN Alauddin Makassar ${ }^{1}$ \\ Lecturer of Tarbiyah and Teaching Faculty of UIN Alauddin Makassar ${ }^{2}$ \\ Lecturer of Dakwah and Communication Faculty of UIN Alauddin Makassar ${ }^{3}$ \\ asniati.gmail.com ${ }^{1}$, laode.ismail@uin-alauddin.ac.id ${ }^{2}$, \\ arifuddin.tike@uin-alauddin.ac.id ${ }^{3}$
}

\begin{abstract}
The main problem of this study is how can the work motivation influence the librarian performance in UPT Library of Universitas Hasanuddin Makassar. Then, this problem is broken down into some sub-problems or research questions, such as 1) how is the work motivation in UPT Library of Universitas Hasanuddin Makassar, 2) how is the librarian performance in UPT library of Universitas Hasanuddin Makassar, and 3) how much is the influence of work motivation toward the librarian performance in UPT library of Universitas Hasanuddin Makassar. This study employed descriptive statistical research with a quantitative approach. The population of this study is all the librarians in UPT library of Universitas Hasanuddin Makassar, with a total number of 33 librarians who became the respondents. The procedure of collecting data in this study used a printed questionnaire. Then, the technique of data analysis was done by using correlation and validity test. This study aims to know about the influence of work motivation toward librarian performance in UPT library of Universitas Hasanuddin Makassar. Based on the result of the data, the variable of work motivation $(\mathrm{X})$ had a strong influence on librarian performance (Y) in UPT library of Universitas Hasanuddin Makassar, the value of pearson correlation was 0,667 or $66.7 \%$, then the significance was $0,000<0,05$. These values showed that the variable of work motivation $(\mathrm{X})$ influence the librarian performance (Y) simultaneously in $45 \%$. Meanwhile, the leftover in 55\% was influenced by other variables. The implication of this study is that the other researchers will take the topic of work motivation toward librarian performance into account and observe it deeply to measure how much is the librarian performance can improve the capacity of library's visitor, which depends on how much motivation that can be given from head of librarian which can affect the prosperity of the librarians.
\end{abstract}

Keywords: Work Motivation; Librarian Performance;

\section{BACKGROUND}

The existence of a library becomes the defining factor of the advancement of a university in supporting tridharma of the university. Thus, a university needs to develop its human resources to support the development of the library in the future. UPT library of Universitas Hasanuddin Makassar is a library of the university named Universitas 
Hasanuddin Makassar. It is a facility that provides sources of literature to fulfil the visitors' need for information. Therefore, the library must develop the human resources to support the achievement of librarian performance for the visitors' interest in compliance with their information needs. ${ }^{1}$

A librarian should have good work motivation so that the main activity of a library can run smoothly. In addition, work motivation can encourage and move the librarian potency so that they want to work productively and actively hunger to achieve the maximum work result. Thus, the purpose of the library can be achieved. ${ }^{2}$

Motivation is a booster for the librarian to do something. Motivation can prompt someone's desire so that person can become a specialist in a certain field of science. It is impossible for someone to learn something well if they do not know the importance and avail of the result that would be achieved from what she/he learned for her/himself. ${ }^{3}$

Based on Undang-Undang number 43 the year 2007 about the library, the librarian is required to do some works: (1) give the optimum services to the visitors; (2) create a conducive atmosphere in the library; and (3) give the good exemplary and maintain the good quality and position based on the duty and responsibility. As explained before, the librarian should give the visitors good services and give well exemplary and maintain the good quality of an institute. ${ }^{4}$

UPT library of Universitas Hasanuddin Makassar is a library owned by Universitas Hasanuddin Makassar. This library has served many book resources in the reading room or can be borrowed by the visitors. However, only the academic communities registered as members are allowed to borrow any kinds of book.

UPT library of Universitas Hasanuddin Makassar is one of the universities that provide facilities and infrastructure to support the university's tridharma (education, research, and community service) to run the library's activity well.

However, based on the observation which the writer did, it was seen that each librarian had a good work motivation so that the activity in the library can be running smoothly. Hence, work motivation in UPT library of Universitas Hasanuddin Makassar has high work motivation. So then, the objective of this study is to figure out how much is the influence of work motivation toward the librarian performance in UPT library of Universitas Hasanuddin Makassar.

\footnotetext{
${ }^{1}$ Larabeng, "Analisis Kinerja Pustakawan dalam Melayani Pengguna Jasa Perpustakaan Pusat Universitas Tadulako", Jurnal Academica Fisip Untad, Vol 5 No. 2 (2013), p. 1093.

${ }^{2}$ Chandra dkk. "Jurnal Ilmu Informasi Perpustakaan dan Kearsipan, Vol. 1, No. 1, (2012), p. 284.

${ }^{3}$ Syardiansah," Hubungan Motivasi Belajar dan Minat Belajar terhadap Prestasi Belajar Mahasiswa Mata kuliah Pengantar Manajemen (Studi Kasus Mahasiswa Tingkat 1 EKM A Semester II)", jurnal manajemen dan keuangan, Vol 5 No. 1 (2016), p. 440.

${ }^{4}$ Perpustakaan Nasional RI, Undang-Undang Republik Indonesia Nomor 43 Tahun 2007 tentang Perpustakaan (Jakarta: Perpustakaan Nasional RI, 2009), p. 15.
} 


\section{THEORETICAL STUDY}

\section{A. Theory of Motivation}

Motivation means "boost and locomotion", which is only given to human, especially to the subordinate or follower. The term of motivation can also be interpreted as a power that exists in human him/herself which cause them to have an ability to act and do something. The motive owned by someone was determined by some needs, both primary and secondary. ${ }^{5}$ Therefore, motivation is conceptualized as the effort that encourages someone to do something born as the locomotion from the inside of the subject to do certain activities to achieve an aim. ${ }^{6}$

The description above can describe that motivation talk about how to encourage someone's desire, in order they want to work hard with giving all of the efforts and skills to embody certain goal.

Motivation has quite variants in some perspectives. Based on the formation review, motivation consists of two models named a) innate motives refer to the motives that are inborn and can be learned, such as an urge to eat, drink, work, etc. This motive is frequently called biological motive; b) learned motives refer to the motives that emerge because it is learned to study the branch of science. This motive is currently called socially required motives because people live in a social environment with the other people, so this motive is formed.

Based on Woodworth and Marquis' view, motivation can be classified into three categories named: a) Motive or organic need, for instance, need to drink, eat, breath, reproduce, act, and get a rest; b) urgent motive, which refers to the urge to survive, respond, try, and hunt. In further, this motive emerges because of external stimulation; c) Objective motives that concern the need to explore, manipulate, and have an interest. These motives exist and are caused by the urge to have the ability to face the real world effectively.

Other perspectives categorized motivation into two points, those are physical motives such as reflex, instinct, self-acting, passion and spiritual motives which formed by religious spirituality. Besides, the other typologies about motivation are a) intrinsic motivation is the motivation that does not need any external stimulus to become active, it happens because each person has their own desire to do something. For instance, someone is reading and nobody ask him/her to do it, he/she wants to find books that he/she can read. So, intrinsic motivation, in this case, is an eager to reach the goal of learning because they really want to know every single thing; b) Extrinsic motivation is the motive which active because of the external stimulus, for example, someone who learns because will be tested and expects to get a good result. So related to that case, extrinsic motivation is a motivation that concerns learning activity that is started and done based on external stimulus, which is scientifically not absolute related to learning activity.

\footnotetext{
${ }^{5}$ Ridwan Rauf." Peranan Kinerja Guru dalam Meningkatkan Motivasi Belajar Peserta Didik Pada Mata Pelajaran Pendidikan Agama Islam Di SMK Negeri 1 Kota Gorontalo”, Thesis (Makassar: Postgraduate program of UIN Alauddin Makassar, 2010), p. 44.

${ }^{6}$ Sitti Husna Abunawas."Pengaruh Motivasi Belajar dan Kecerdasan Intelektual terhadap Prestasi Belajar Siswa MTs As'Adiyah Putra 1 Pusat Sengkah", Thesis (Makassar: Postgraduate program of UIN Alauddin Makassar, 2011), p. 21.
} 
These two motivations show that both of them have the need that should be fulfilled. In intrinsic motivation, there is a need to relieve the urge that each person has in themselves. Meanwhile, extrinsic motivation needs to satisfy their selves by getting a good score. ${ }^{7}$

The objective of giving motivation such as: a) Enhancing the morality and work satisfaction of the employee; b) Enhancing the work productivity of the employee; c) Maintaining the stability of the employee; d) Enhancing the employee's discipline; e) Enhancing the effectiveness of the employee; f) Creating the good atmosphere and relation; g) Enhancing loyalty, creativity, and participation of the employee; h) Enhancing the employee's prosperity; and i) Enhancing the responsibility from each employee to their job.

Based on the objectives of motivation above, it can be said that it is really important to give motivation toward the employees. Motivation can develop their productivity and performance. Wherefore, sometimes some employees get saturation, lazy, and bored on their work, if the employees experience it, some features can be seen: the absence increased, discipline is getting degenerate, the service is less satisfying, many of the employees resign and the fresh applicant that just started to work. ${ }^{8}$

The function of motivation is a) Encouraging behavior or an action. Without motivation, there will be no action such as learning; b) Motivation functions as a guide, meaning to move actions towards achieving the desired goals; c) Motivation functions as a mover. This motivation has functioned like a machine; the size of the motivation will determine the speed of the work. ${ }^{9}$

Motivation is very important for librarians to improve their performance because motivation is what causes, distributes and supports human behaviour to work and is enthusiastic in achieving optimal results. To motivate librarians, leaders must know the motives desired by librarians, both conscious and unconscious needs, in the form of material or non-material, physical and spiritual needs

Every librarian carrying out his work has job recruitment, namely the demands that the individual who carries it out must be met. Therefore, the success implementation of a job will be greatly influenced by the suitability between the requirements of the job and the motivation brought by the librarian concerned. So motivation is an essential factor that encourages librarians to work and be enthusiastic. ${ }^{10}$

\section{B. Theory of Librarian Performance}

Performance is the result of work that a person or group of people can achieve in an organization in accordance with their respective authorities and responsibilities to achieve

\footnotetext{
${ }^{7}$ Sardiman, Interaksi dan Motivsi Belajar Mengajar (Cet. XXII; Ed.1; Jakarta: Rajawali Pers, 2014), p. 86 .

${ }^{8}$ Ridwan Isya Luthfi," Pengaruh Motivasi terhadap Kinerja Karyawan (Studi Pada PT Elsiscom Prima Karya, Kantor Perwakilan Surabaya)”, Jurnal Administrasi Bisnis, Vol 13 No. 1 (2014), p. 2.

9Syardiansah," Hubungan Motivasi Belajar dan Minat Belajar terhadap Prestasi Belajar Mahasiswa Mata kuliah Pengantar Manajemen (Studi Kasus Mahasiswa Tingkat 1 EKM A Semester II)", jurnal manajemen dan keuangan, Vol 5 No.1 (2016), p. 442.

${ }^{10}$ Ernawati Nasution," Motivasi Kerja dalam Meningkatkan Produktivitas Kerja Pegawai Fakultas Dakwah IAIN Ar- Raniry”, jurnal Al-Bayan, vol 20 no 29 (2014), p. 5.
} 
the goals of the organization concerned legally not violating the law and in accordance with morals and ethics. ${ }^{11}$

Then according to the code of ethics of the Indonesian Librarians Association in his book " Kamus Istilah Perpustakaan ", it is said that the so-called librarian is someone who carries out library activities by providing services to the community in accordance with the duties of the parent institution based on library science, documentation and information that he has through education. The word librarian comes from the word "library" by adding the suffix 'an', defined as a person whose job or profession is related to the world of libraries or library materials. ${ }^{12}$

\section{RESEARCH METHOD}

Descriptive statistic research with a quantitative approach is research that contains efforts to collect numeric data and uses deductive logic in developing and testing theories as is generally used in the natural sciences and positivist social sciences that have a view of all phenomena as objective. This type of descriptive statistic research is a type of research that functions to describe or provide an overview of the object under study through sample or population data as well as the location and time of the study. This research was conducted at UPT Hasanuddin University Library Makassar. The type of population that the author uses is a type of static population.

The sample in this study were all librarians at the UPT Library of Hasanuddin University Makassar as many as 33 respondents. Methods of collecting data through observation, documentation, surveys. The instrument that the author uses is a questionnaire (questionnaire). Validity and reliability tests were used with the help of the IBM SPSS V22 program. Data processing and analysis techniques using correlation tests and regression tests using SPSS software.

\section{IV.FINDINGS AND DISCUSSIONS}

Data analysis was carried out based on the distribution of questionnaires carried out to librarians at the UPT Library of Hasanuddin University Makassar, with a sample of 33 respondents. The characteristics of the respondents for the male are 13 people, and the respondents for the female are 20 people. This research focuses on the work motivation and librarians' performance at UPT Hasanuddin University Makassar Library.

The results of the respondent description test by gender

\begin{tabular}{|ll|r|r|r|r|}
\hline & & & & \multicolumn{2}{c|}{ Cumulative } \\
& Frequency & Percent & Valid Percent & \multicolumn{2}{|c|}{ Percent } \\
\hline Valid & Male & 13 & 39.4 & 39.4 & 39.4 \\
& Female & 20 & 60.6 & 60.6 & 100.0
\end{tabular}

\footnotetext{
${ }^{11}$ Tessa Simahate. Pengaruh Intensif terhadap Peningkatan Kinerja Pustakawan di Perpustakaan UNIMED”, Jurnal Iqra, Vol 12 No. 2 (2018), p. 42.

${ }^{12}$ Julian Wirano, "Pengaruh Motivasi terhadap Kinerja Pustakawan Badan Perpustakaan Arsip dan Dokumentasi Provinsi Sulawesi Utara", Jurnal Acta diurnal, Vol. 4 No. 4 (2015), p. 4.
} 


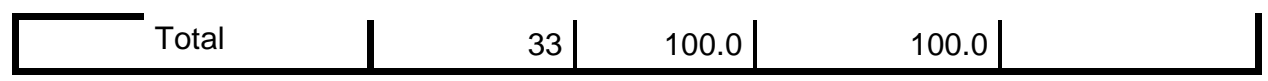

The description of respondents based on gender above shows that 13 respondents $(39.4 \%)$ are male and the remaining 20 respondents $(60.6 \%)$ are female. Therefore, the total is 33 respondents.

Based on the results of data processing for the work motivation variable (x) with a total of 10 statement items, the total score for the work motivation variable was 1,193. Based on the assessment of 33 respondents, the value of the work motivation variable was 1,238, with a score range (330-1,320). The score of 1,238 based on the score range chart is included in the good interval and close to very good. Based on the results of the calculation of the range of scores, it is known that there is an influence of work motivation at the UPT Library of Hasanuddin University Makassar on the performance of librarians

Variable Validity Test Results (X) Work Motivation

\begin{tabular}{|c|c|c|c|}
\hline Item & r Table & r Count & Exp. \\
\hline X1 & 0,344 & 0,601 & Valid \\
\hline X2 & 0,344 & 0,489 & Valid \\
\hline X3 & 0,344 & 0,629 & Valid \\
\hline X4 & 0,344 & 0,788 & Valid \\
\hline X5 & 0,344 & 0,565 & Valid \\
\hline X6 & 0,344 & 0,789 & Valid \\
\hline X7 & 0,344 & 0,522 & Valid \\
\hline X8 & 0,344 & 0,533 & Valid \\
\hline X9 & 0,344 & 0,700 & Valid \\
\hline X10 & 0,344 & 0,822 & Valid \\
\hline
\end{tabular}

Based on the data processing results for the librarian's performance variable (y) in the UPT Library of Hasanuddin University Makassar, with 9 statement items. Based on the assessment of 33 respondents, the total score for the librarian's performance variable was 1,113 , with a score range (297-1.188). The value of 1.113 based on the score range chart for the librarian's performance variable is included in the assessment interval that is not good and close to very bad, which means that the librarian's performance has a very small effect on work motivation. 


\section{Variable Validity Test Results (Y) Librarian Performance}

\begin{tabular}{|c|c|c|c|}
\hline Item & r Table & r Count & Exp. \\
\hline Y1 & 0,344 & 0,692 & Valid \\
\hline Y2 & 0,344 & 0,772 & Valid \\
\hline Y3 & 0,344 & 0,734 & Valid \\
\hline Y4 & 0,344 & 0,747 & Valid \\
\hline Y5 & 0,344 & 0,515 & Valid \\
\hline Y6 & 0,344 & 0,682 & Valid \\
\hline Y7 & 0,344 & 0,777 & Valid \\
\hline Y8 & 0,344 & 0,813 & Valid \\
\hline Y9 & 0,344 & 0,623 & Valid \\
\hline
\end{tabular}

Furthermore, to determine the effect of work motivation on the performance of librarians at the UPT Library of Hasanuddin University Makassar, the correlation test results show that the Pearson correlation value between the work motivation variable (X) and the librarian's performance $(\mathrm{Y})$ has a relationship of 0.667 . This means that the correlation value is in the interval 0.060-0.799. So it can be understood that there is a (strong) relationship between work motivation and librarian performance.

The regression analysis results obtained the equation of work motivation $(\mathrm{X})$ on the performance of librarians (Y), namely $\mathbf{Y}=\mathbf{7 . 6 8 0}+\mathbf{0 . 1 3 1} \mathbf{X}$. This means that if there is no increase in work motivation, the librarian's performance will remain at 7.680. on the other hand, if the motivation value increases, the librarian's performance will increase by 0.131 units. This means that with increasing work motivation, the performance of librarians will be higher, and vice versa.

From the hypothesis test results of this study, the results of the regression test showed that the value of work motivation on the performance of librarians was 0.667 with a significance level of $0.000<0.05$, it can be concluded that there is an influence of work motivation on the performance of librarians. The coefficient of determination of work motivation that affects librarians' performance is 0.445 , which means $45 \%$. At the same time, other variables influence the remaining $55 \%$.

\section{CONCLUSION}

Based on the correlation test results, it is known that the result is 0.667 with an interval of 0.060-0.799. So it can be understood that there is a (strong) relationship between work motivation and the performance of librarians at UPT Hasanuddin University Makassar Library. With a significance level of $0.000<0.05$, there is sufficient evidence to reject $\mathrm{H} 0$; $\mathrm{p}=0$ and accepts $\mathrm{H} 1 ; \mathrm{p} 0$ so the correlation is significant. The magnitude of the influence of work motivation on the performance of librarians at the UPT Library of Hasanuddin University Makassar. The calculation results are $45 \%$ while other variables influence the remaining $55 \%$.

This research implies that there will be a review of the work motivation on the librarians performance. It will measure the librarians' performance and how they increase 
library visitors' capacity depending on the motivation given by the head of the library, which will impact the welfare of the librarian.

\section{REFERENCES}

Abu Nawas, Sitti Husna."Pengaruh Motivasi Belajar dan Kecerdasan Intelektual terhadap Prestasi Belajar Siswa Mts As’Adiyah Putra 1 Pusat Sengkah", Tesis, Makassar: Pascasarjana UIN Alauddin Makassar, 2011.

Chandra, dkk. Jurnal Ilmu Informasi Perpustakaan dan Kearsipan Vol. 1, No. 1, Tahun 2012.

Larabeng. Analisis Kinerja Pustakawan dalam Melayani Pengguna Jasa Perpustakaan Pusat Universitas Tadulako", Jurnal Academica Fisip Untad, Vol. 5 No. 22013.

Luthfi, Ridwan Isya. Pengaruh Motivasi terhadap Kinerja Karyawan (Studi Pada PT Elsiscom Prima Karya, Kantor Perwakilan Surabaya)", Jurnal Administrasi Bisnis, Vol. 13 No. Tahun 2014.

Nasution, Ernawati. Motivasi Kerja dalam Meningkatkan Produktivitas Kerja Pegawai Fakultas Dakwah IAIN Ar- Raniry”, Jurnal Al-Bayan, Vol. 20 No. 29 Tahun 2014.

Perpustakaan Nasional RI. Undang-Undang Republik Indonesia Nomor 43 Tahun 2007 Tentang perpustakaa. Jakarta: Perpustakaan Nasional RI, 2009.

Rauf, Ridwan.” Peranan Kinerja Guru dalam Meningkatkan Motivasi Belajar Peserta Didik Pada Mata Pelajaran Pendidikan Agama Islam Di SMK Negeri 1 Kota Gorontalo", Tesis (Makassar: Pascasarjana UIN Alauddin Makassar, 2010.

Sardiman, Interaksi dan Motivsi Belajar Mengajar Cet. XXII; Ed.1; Jakarta: Rajawali Pers, 2014.

Simahate, Tessa. Pengaruh Intensif terhadap Peningkatan Kinerja Pustakawan di Perpustakaan UNIMED” Jurnal Iqra, vol 12 No. 2 Tahun 2018.

Syardiansah. Hubungan Motivasi Belajar dan Minat Belajar terhadap Prestasi Belajar Mahasiswa Mata kuliah Pengantar Manajemen (Studi Kasus Mahasiswa Tingkat 1 EKM A Semester II)”, Jurnal Manajemen Dan Keuangan, Vol. 5 No.1 Tahun 2016.

Wirano, Julian. Pengaruh Motivasi terhadap Kinerja Pustakawan Badan Perpustakaan Arsip dan Dokumentasi Provinsi Sulawesi Utara”, Jurnal Acta Diurnal, Vol. 4 No. 4 Tahun 2015. 